\title{
Plankton Biodiversity in The Burai River of Ogan Ilir District, Sumatera Selatan
}

\author{
Awalul Fatiqin \\ Universitas Islam Negeri Raden Fatah, Palembang, South Sumatera, Indonesia \\ Corresponding author: awalulfatiqin_uin@radenfatah.ac.id
}

\begin{abstract}
The purpose of this study was to determine the abundance of plankton in the Ogan Ilir regency of South Sumatra. Samples were obtained using a purposive random sampling method with plankton as the main material for measuring abundance and the Shannon Wiener Diversity Index (H), Simpson Dominance Index (C), and plankton abundance index. The results of the study obtained six classes consisting of 15 genera of plankton including Fragielaria, Synedra, Eunotia, Diatom, Fustulia, Oedogonium, Gonium, Chaetophora, Microspora, Allona, Neuplius, Lyngbya, Spirulina, Cyclotella and Dismidium. Diversity value at point 1 (1.75) with medium category, point 2 (3.5) with high category, point $3(0.75)$ with the medium category. The diversity value of three points is known to be low in population.
\end{abstract}

Keywords: Biodiversity, Zooplankton, Phytoplankton, South Sumatra.

\section{Introduction}

Plankton is an aquatic organism that lives passively floating in bodies of the water, and the mobility is influenced by the flow of water (Arinardi et al. 1997). Organisms that live floating in the water, plankton, have minimal movement so that it will be carried away, and plankton itself is unable to move against the water flow (Odum, 1994). Plankton categorized in the phytoplankton and zooplankton. Phytoplankton is found in the entire mass of the water surface, it is allowing to be exposed to sunlight for photosynthesis (Fachrul, 2007).

Flow velocity is the main factor in the abundance of phytoplankton directly (Barus, 2004). The phytoplankton community is a commonly found algae group. These algae are included Chlorophyceae (green algae), Xanthophyceae (yellow-green algae), Chrysopyceae (golden-brown algae), Bacillariophyceae (diatoms), Euglenophyceae (euglenoids), Dinophyceae (dinoflagellates) (Ferris et al. 2010). Zooplankton performs vertical migration aimed at avoiding predation by predators that detect prey vertically and adjust to the environment due to changing temperature changes (Barus, 2004). Vertical movement is a universal phenomenon carried out by zooplankton influenced by light and temperature. Zooplankton conducts vertical migration to avoid predators visually as a mechanism to increase production and save energy (Nybakken, 1992).

The measurement of the density of plankton uses a sampling method that involves the calculation of organisms that are large enough, and the amount can be used to obtain rough estimates of density in the area sampled (Saros JE, 2000). The phytoplankton community structure showed a non-significant relationship with nutrient availability, but correlated significantly with salinity, dissolved oxygen, and brightness parameters (Indra 
et al. 2015). In line with (Handayani \& Syahputra, 2018) Current velocity and light penetration affect the diversity of aquatic biota in Mulur Reservoir Sukoharjo, Central Java, Indonesia substantially.

Zooplankton can increase aquatic biogeochemical processes, thereby increasing the abundance of zooplankton in the waters (Cavan et al. 2017). The salinity of river waters affects the abundance of zooplankton communities and their structure, but not the diversity of zooplankton communities but has a significant correlation value between the level of salinity, number of species, abundance, and biomass of zooplankton (Paturej \& Gutkowska, 2015). The South Sumatra region has a large diversity of aquatic sources that have environmental characteristics that can describe the diversity of plankton. The previous study conducted in Banyuasin Regency showed the value of the diversity index is medium (Anggraini Yusanti \& Widayatsi, 2018). Along with research (Luthfia, 2013), it showed a high diversity of zooplankton in the waters of the Telo Island River.

The Ogan Ilir District river has a variety of biotic factors (fish diversity), however, physical qualities such as odor, turbidity, the presence of heavy metals, and coliforms show deficient water quality (Amallia, 2019). This research is performed to identify biodiversity of Plankton in the Burai River, Ogan Ilir Regency, South Sumatra by comparing biotic factors (fish diversity) and physical factors in the water.

\section{Material and Method}

The water samples were taken on the Burai river in South Sumatera. The research method was carried out using Purposive Random Sampling, which based on differences in the environmental zones around the river banks by determining 3 Stations. Plankton sampling was carried out by the filtration method (Suwondo dan Febrita. 2004). Plankton samples taken from the study site by taking 50 liters/point of water.

The identification of plankton is carried out in the laboratory to the genus level. The bottle containing the plankton sample is shaken slowly by turning the container 3 to 4 times until it is homogeneous. The sample solution was taken using a pipette, then dropped into a $1 \mathrm{ml}$ Sedgwick Rafter Counting Cell to be observed under a microscope with a magnification of $10 \times 10$. Observations were made in duplicate using a standard identification book (Luthfia, 2013), identification refers to an identification book (Davis, 1955; Bold, 1985; Edmonson, 1983).

Quantity index analysis of the diversity index analyzed by the Shanon-Wiener diversity index formula (Odum, 1994).

$\begin{array}{ll} & \mathbf{H}=-\boldsymbol{\Sigma}(\mathbf{n i} / \mathbf{N}) \ln (\mathbf{n i} / \mathbf{N}) \\ \mathrm{H} & : \text { Index diversity } \\ \mathrm{ni} & : \text { Number of individual types } \\ \mathrm{N} & : \text { Total number of individuals }\end{array}$


A uniformity index (E) value can be calculated using the formula: Shanon-Wiener (Odum, 1994).

$$
\mathrm{E}=\boldsymbol{H}^{\prime} / \text { Ins }
$$

E $\quad$ : Index type

$\mathrm{H}^{\prime} \quad$ : Biodiversity Index

S : Number of types found

\section{Results and Discussion}

\subsection{Results}

Based on the process of research carried out the data of plankton diversities in the rivers of Ogan Ilir South Sumatera Regency (See Table 1).

Table 1. The results of Plankton observation at Burai River, South Sumatera

\begin{tabular}{|c|c|c|c|}
\hline No & Class & Genus & Total \\
\hline \multirow[t]{5}{*}{1} & Bacillariophyceae & Fragielaria & 4 \\
\hline & & Synedra & 2 \\
\hline & & Eunotia & 4 \\
\hline & & Diatoms & 5 \\
\hline & & Fustulia & 1 \\
\hline \multirow[t]{4}{*}{2} & Chlorophyceae & Oedogonium & 4 \\
\hline & & Gonium & 1 \\
\hline & & Chaetophora & 1 \\
\hline & & Mikrospora & 1 \\
\hline \multirow[t]{2}{*}{3} & Bravichiopoda & Allona & 1 \\
\hline & & Neuplius & 1 \\
\hline \multirow[t]{2}{*}{4} & Cyanophyceae & Lyngbya & 1 \\
\hline & & Spirulina & 1 \\
\hline 5 & Coscinodiscophyceae & Cyclotella & 1 \\
\hline 6 & Zygnrmatophyceae & Dismidium & 1 \\
\hline
\end{tabular}

Table 1 shows the Data on the acquisition of plankton in each station showed different abundance, from the three Station, acquire 29 individual plankton obtained from Station 1 has 7 individuals, Station 2 has 21 individuals and Station 3 has 1 individual. Each station has environmental characteristics and showed different abundance.

Table 2. Diversity index Results ( $\left.\mathrm{H}^{\prime}\right)$

\begin{tabular}{cccc}
\hline Station & Diversity Index Station (H') & Value* & Category* \\
\hline 1 & 1,17 & $\mathrm{H}^{\prime} \leq 2.0$ & Low \\
2 & 3.50 & $\mathrm{H}^{\prime} \geq 3.0$ & High \\
3 & 0.17 & $\mathrm{H}^{\prime} \leq 2.0$ & Low \\
\hline
\end{tabular}

*:(Odum, 1993). 
Table 3. Index uniformity results (E)

\begin{tabular}{cccc}
\hline Stasion & Uniformity index (E) & Value* & \multicolumn{1}{c}{ Category* } \\
\hline 1 & 0.10 & $\mathrm{E}<0.5$ & $\begin{array}{l}\text { Low population uniformity, } \\
\text { depressed community } \\
\text { Low population uniformity, } \\
\text { depressed community } \\
3\end{array}$ \\
0.15 & $\mathrm{E}<0.5$ & $\mathrm{E}<0.5$ & $\begin{array}{l}\text { Low population uniformity, } \\
\text { depressed community }\end{array}$ \\
\hline
\end{tabular}

*:(Odum, 1993).

Table 4. Dominance Index Results (C)

\begin{tabular}{cccc}
\hline Stasion & $\begin{array}{c}\text { Dominancy Index } \\
\text { (E) }\end{array}$ & Value* & Category \\
\hline 1 & 0.01 & $0.00<\mathrm{C}<0.5$ & Low \\
2 & 1.00 & $0.75<\mathrm{C} \leq 1$ & High \\
3 & 1.00 & $0.75<\mathrm{C} \leq 1$ & High \\
\hline
\end{tabular}

*:(Odum, 1993).

\subsection{Discussion}

Based on the results of research that has been done in Burai River Ogan Ilir Regency found 6 classes that include 15 species of plankton, from class Bacillariophyceae there are 5 genera, Chlorophyceae there are 4 genera, Bravichiopoda there are 2 Genus, Cyanophyceae there are genus, there is only one genus in the classes Coscinodiscophyceae and Zygnrmatophyceae. The diversity of Cyanophyceae in water can be used as a bioindicator in the monitoring of water quality. When water dominated by species from the Cyanophyceae class or blue-green algae, the waters can indicate pollution (Vincent, 2009). One example of Cyanophyceae class is Synedra sp., where the dominancy of the Synedra sp. can be used as an indication of water quality (pollution) (Cavan et al., 2017).

This group of class Bacillariophyceae can found in virtually every aquatic environment that gets enough sunlight to sustain activity. Synedra. sp has a high abundance and can be found in various habitats such as wet soil, stone walls, steep corals, peat and bark, can be seen as a yellow froth above the mud on the ditch or pond. Some diatoms live as epiphytes on other algae or wild plants (Indra et al., 2015).

Synendra is also known to have a defensive ability to change unfavorable environmental conditions (Paturej \& Gutkowska, 2015). Synedra also is able to survive in a low nutrient (oligotrophic) environment with low nitrogen and phosphate concentrations. That is because Synedra sp. is capable of accumulating nutrients and storing them as food reserves in the form of undissolved polymers (Vincent, 2009). Eunotia is a large genus consisting of about 200 species (Swale, 1978). The genus has extensive distribution around the world, although many species have limited distribution in tropical areas, large genus distributions due to low $\mathrm{pH}$ water environment preference and conductivity to be the most abundant and diverse Genus in this area (Prasad AKSK, 1990). 
Atoms as a bioindicator of many aquatic qualities in various countries of its application in paleoreconction of environmental change. This is in line with the development of multivariate statistical analysis implementation for paleoreconction analysis (Indra et al., 2015). The potential of diatoms as bioindicators is better compared to other groups of organisms. This advantage is due to the broad distribution, variation population, important in the food chain, found on almost all substrates (capable of recording habitat history), short life cycle and rapid reproduction, many species are sensitive to changes environment, able to reflect changes in the water quality in the short and long term, easy to pollute; management and identification $(H, 2002)$.

Oedogonium belonging to the family Oedogoniaceae and the order of Oedogoniales have irregular oedogantuni, the diameter is about $350 \mathrm{~mm}$. Parietal mesh Chloroplas, with some pyrenoid. A thickened wall at one end of a few other cells, one instinct (Swale, 1978). Oedogonial is a group of freshwater green algae, which grow in quiet situations and are usually avoided flowing water. Oedogoniaceae consists of 3 genera (Oedocladium, Bulbochaete, and Oedogonium) with approximately 400 species. The distinctive characteristic of Oedogonium family's chlamydomonadales order is oedogoniales family Oedogoniaceaegenus Oedogonium. Not assembled microspara filament with the size around 5-25 um. The cell has many parietal chloroplasts and some structures similar to that of Tribonema (Swale, 1978).

Allona is the larva of a crustacean according to (Fachrul, 2007), the zooplankton that lives in the waters are very diverse, consisting of various forms of larvae and adults. While according to (Saros JE, 2000), the most prominent is the crustacean planktonic. When reviewed from the ecological aspect, the most important crustacean members are copepods. Nauplius is included in the Meroplankton, which is the larva of the Cyclops included in the Guinea Arthropoda, the Cyclopoidea is a member of the Cyclops, which has the ability to adapt to the polluted environment if its existence is found Environmental pollution indicators (Edmonson, 1983). Lyngbya is a genus of cyanobacteria, a unicellular autotroph that forms the basis of the food chain. As a result of the genetic analysis of some genera such as Moorea, Limnoraphis, Oceania, Microseira and Davis, common in lakes, ponds, springs, wetlands, rivers, and rivers. They play a major role in nitrogen, carbon, and oxygen dynamics from Many aquatic environments (Vincent, 2009).

Cyanobacteria photosynthesis uses water as an electron donor and generates oxygen as in algae, although a small number of strains can also be used hydrogen sulfide $\left(\mathrm{H}_{2} \mathrm{~S}\right)$ and turn it into a sulfur element. In general, cyanobacteria can tolerate low oxygen conditions and the concentration of toxic $\mathrm{H}_{2} \mathrm{~S}$ for eukaryotic algae. These tolerances can contribute their ability to survive in the Eutropik anoxic Lake sediment as well as in a particular mat environment (Vincent, 2009). Spirulina is a widely spread microalgae that can be found in various types of environments, both in brackish, marine and freshwater waters. Its morphological characteristics are filament which is composed of a spiralshaped multicellular trichome that joins into one, has a columnar cell forming a twisted filament resembling a spiral, unbranched, autotroph and turquoise in color (Odum, 1994). 
Cyclotella has the ability to endure a wide range of environmental conditions, although freshwater organisms and only eight species (C. caspia, C. Choctawhatcheeana, C. Cryptica, C. Quillensis, C. Litoralis, C. Meneghiniana, C. Striata and C. Stylorum) have been found inhabiting seawater (Prasad AKSK, 1990). In the last few years, the Diatomic centric are explored in the lakes and the estuary, it has begun to receive greater attention, especially the genus Cyclotella $(H, 1996),(H, 2002)$. Cyclotella taxonomy is difficult to unravel due to considerable morphological variations among the species (Hakansson $\mathrm{H}$, 1994), (Meyer B, 1996).

Diatom are usually formed from biota in Saline lakes (Saros JE, 2000). On Alchichica Lakes, Puebla Mexico, diatom assemblages include 10 species from total 19 alga species (Oliva MG, 2001). Based on the result of counting the abundance of plankton in table 1, it can be known that the amount of abundance of plankton in the waters of Burai River is 29 individuals/L. The low abundance of plankton in Burai Rivers due to this water quality, are low. Based on its diversity abundance it can be noted that human activities, such as the absence of waste treatment around the water, will affect the abundance of plankton. As expressed by (Odum, 1993), the community activity directly or indirectly will affect the quality of water that can be caused by the use of various artificial fertilizers, pesticide waste disposal.

A heavy water zone or habitat is a shallow area, the current speed is high enough to cause a clear river base from deposits and other material that is loose so it is essentially solid. This zone has a specially adapted plankton or parasitic organisms that can cling or hold strong to a solid base (Odum, 1993). According to (Odum, 1994), generally, the river shows the two main habitats seen from the current velocity and the basic substrate where the water habitat is calm and swift so that there are two types of ecosystems on river flow. A diversity index is used to look at the level of stability of a community or show the condition of the community structure from the diversity of organisms contained in an area. Diversity ( $\left.\mathrm{H}^{\prime}\right)$ illustrates the total proportion of a species relative to the total number of individuals present. The number of species with balanced proportions indicates higher diversity. High-quality waters have a high variety of diversity and vice versa in bad or polluted waters usually have a low diversity of types (Fachrul, 2007).

\section{Conclusion}

Found 6 classes consisting of 15 species of plankton including Fragielaria, Synedra, Eunotia, Diatom, Fustulia, Oedogonium, Gonium, Chaetophora, Microspores, Allona, Neuplius, Lyngbya, Spirulina, Cyclotella, and Dismidium. The value of diversity at point 1 (1.75) with medium category, point 2 (3.5) with high category, point $3(0.75)$ with a medium category. The diversity value of the three dots shows its low population diversity.

\section{References}

Anggraini Yusanti, I., \& Widayatsi, T. (2018). Keanekaragaman Zooplankton Di Rawa Banjiran Desa Sedang Kecamatan Suak Tapeh Kabupaten Banyuasin. Jurnal Biota, 
$4(7), 7-11$.

Arinardi, O.H., Sutomo, A.B., Yusuf, S.A., Trimaningsih, Asnaryanti, E., Riyono, S. H. (1997). Kisaran Kelimpahan dan Komposisi Plankton Predominan di Perairan Kawasan Timur Indonesia.

Barus, T. (2004). Pengantar Limnologi Studi Tentang Ekosistem Air Daratan. Medan: USU Press.

Bold, H. C. dan W. M. J. (1985). Introduction to the Algae Second Edition. New Jersey USA: Inc. Englewood Clitts.

Cavan, E. L., Henson, S. A., Belcher, A., \& Sanders, R. (2017). Role of zooplankton in determining the efficiency of the biological carbon pump. Biogeosciences, 14(1), 177186. https://doi.org/10.5194/bg-14-177-2017

Davis, C. C. (1955). The Marine and Fresh-water Plankton. Amerika: The Michigan State University Press.

Edmonson. (1983). Fresh Water Biology, 2 nd edition. New York: John Wiley and Sons Inc.

Fachrul, M. F. (2007). Metode Sampling Bioekologi. Jakarta: Bumi Aksara.

Ferris, P. J., Olson, B., de Hoff, P. L., Douglass, S., Casero, D., Prochnik, S. E., et al. (2010). Evolution of an expanded sex-determining locus in Volvox. Science, 328(5976), 351354.

H, H. (1996). Cyclotella striata complex: tipification and new combinations. Diatom Research, 11, 241-260.

H, H. (2002). A compilation and evaluation of species in the general Stephanodiscus, Cyclostephanos and Cyclotella with a new genus in the family Stephanodiscaceae. Diatom Research, 17, 1-139.

Hakansson H, K. H. (1994). Cyclotella agassizensis nov. sp. and its relationship to C. quillensis Bailey and other prairie Cyclotella species. Diatom Research, 9(15), 289301.

Handayani, L., \& Syahputra, F. (2018). Depik Depik. Depik, 7(1), 76-83. https://doi.org/10.13170/depik.7.1.8838

Hoetary, R. A., \& Amallia, T. (2019). Water Quality Analysis of Kelekar River in Burai Village Kecamatan Tanjung Batu / Tanjung Batu Subdistrict Kabupaten Ogan Ilir/ Ogan Ilir District to Identify the Toxic Effects Caused, 5(1), 48-54.

Indra, S., Putri, P., Hikmah, S., \& Sari, J. (2015). Community strucure of phytoplankton and its ralationship to nutrient availability and other water quality parameters in Eastern 
of Surabaya Coastal Waters, 4(2), 79-86.

Luthfia. (2013). Keanekaragaman Zooplankton di Perairan Sungai Pulau Telo Kec Selat kabupaten Kapuas. Jurnal Wahana-Bio, X, 76-93.

Meyer B, H. H. (1996). Morphological variation of Cyclotella polymorpha sp. nov. (Bacillariophyceae). Phycologia, 35, 64-69.

Nybakken, J. W. (1992). Biologi Laut : Suatu Pendekatan Ekologis. Diterjemaahkan oleh H. M. Eidman, Koesoebiono, D. G. Bengen, M. Jakarta: PT Gramedia.

Odum, E. (1993). Dasar-Dasar Ekologi. Terjemahan Tjahjono Samingan,.Edisi 3. Yogjakarta: Universitas Gajah Mada.

Odum, E. (1994). Dasar-Dasar Ekologi. Terjemahan Tjahjono Samingan,Edisi 3. Yogjakarta: Universitas Gajah Mada.

Oliva MG, L. A. (2001). Phytoplankton dynamics in a deep, tropical, hyposaline lake. Hydrobiologia, 466(3), 299-306.

Paturej, E., \& Gutkowska, A. (2015). The effect of salinity levels on the structure of zooplankton communities. Archives of Biological Sciences, 67(2), 483-492. https://doi.org/10.2298/ABS140910012P

Prasad AKSK, N. J. (1990). The genus Cyclotella (Bacillariophyta) in Choctawhatchee Bay, Florida, With Special Reference to C. striata and C. choctawchee sp. Phycologia, 50, 418-436.

Saros JE, F. S. (2000). Changes in the growth rates of saline-lake diatoms in response to variation in salinity, brine type and nitrogen form. Journal of Plankton Research, 22, 1071-1083.

Suwondo, Febrita. E, S. . . (2004). Struktur Komunitas Gastropoda pada hutan mangrovedipulau sipora kabupaten kepulauan mentawai Sumatra barat. Jurnal Biogenesis, 2(1).

Swale, l. B. (1978). A beginner's guide to Freshwater Alga. London: Her Majesty s Slaiionery Office.

Vincent, W. F. (2009). Cyanobacteria. Canada, Laval University, Quebec City, QC, Canada: Elsevier Inc. All rights reserved. 